\title{
Pelatihan Manajemen Bersosial Media Dalam Strategi Pemasaran Paguyuban Jip4x4 Bromo Tengger Semeru Kabupaten Malang
}

\author{
Mariana Puspa Dewi ${ }^{1}$, Lussia Mariesti Andriany $^{2}$, Justita Dura ${ }^{3}$, Fadilla \\ Cahyaningtyas ${ }^{4}$, Mulyaningtyas ${ }^{5}$ \\ 1,2,3,4,5Institut Teknologi dan Bisnis Asia Malang \\ ${ }^{*}$ Corresponding author \\ E-mail: doora030387@gmail.com (Justita Dura)*
}

\section{Article History:}

Received: 5-5-2020

Revised: 21-7-2020

Accepted: 5-8-2020

\section{Abstract:}

Paguyuban Jip Bromo Tengger Semeru merupakan salah satu UMKM yang terletak di Jawa Timur dengan usaha transportasi ke Bromo Semeru. UMKM ini merupakan usaha yang berbeda dengan lainnya, di mana tujuannya adalah untuk meningkatkan kesejahteraan bersama. Untuk itu, pengelolaan pemasaran paguyuban Jip harus dapat dilakukan secara produktif, efektif, dan efisien. Untuk mencapai kemampuan pengelolaan tersebut, umkm ini harus dapat berusaha secara luwes sehingga mampu bersaing dengan pelaku ekonomi lainnya dalam menjalakan usahanya. Salah satunya disebabkan kurang professionalnya pengurus dalam mengelola usahanya. Oleh karena itu, paguyuban Jip ini harusnya mampu meningkatkan kualitas pengelolaan pemasaran dalam bersosial media. Tujuan dalam pelatihan adalah para pengurus dan anggota paguyuban bisa mengelola social media dengan baik dalam melakukan pemasaran jasa. Metode pengabdian yang digunakan dengan melalui pelatihan dengan metode presentasi, Tanya jawab, dan praktik. Dengan adanya pelatihan manajemen bersosial media ini, tingkat pemasaran para driver jip bromo tengger semeru diharapkan bisa meningkat.

Keywords: $\quad$ Sosial Media, Pemasaran Jasa, UMKM 


\section{Pendahuluan}

Paguyuban Jip Bromo Tengger Semeru merupakan salah satu UMKM yang terletak di Jawa Timur dengan usaha transportasi ke Bromo Semeru. UMKM ini merupakan usaha yang berbeda dengan lainnya, di mana tujuannya adalah untuk meningkatkan kesejahteraan bersama. Untuk itu, pengelolaan pemasaran paguyuban Jip harus dapat dilakukan secara produktif, efektif, dan efisien. Untuk mencapai kemampuan pengelolaan tersebut, umkm ini harus dapat berusaha secara luwes sehingga mampu bersaing dengan pelaku ekonomi lainnya dalam menjalakan usahanya. Namun tidak semua umkm mampu dalam menghadapi tantangan tersebut. Salah satunya disebabkan kurang professionalnya pengurus dalam mengelola usahanya. Oleh karena itu, paguyuban Jip ini harusnya mampu meningkatkan kualitas pengelolaan pemasaran dalam bersosial media. Selain itu, strategi pemasaran diperlukan dalam upaya meningkatkan kemampuan bersaing dengan pelaku usaha lainnya.

Tentunya, untuk mencapai keunggulan kompetitif, UKMdapat memanfaatkan teknologi yang sedang berkembang pesat saat ini. Teknologi yang dimaksud adalah internet dan media sosial. Peran media social dapat dimanfaatkan kini mulai beralih. Awalnya sosial media berperan sebagai media komunikasi antar individu, namun kini telah berubah menjadi bagian penting dalam dunia bisnis. (Öztamur dan Karakadılar, 2014) menyatakan bahwa media social berperan sebagai alat pemasaran baru yang penting dalam dunia bisnis. Media Sosial menawarkan metode komunikasi pemasaran yang unik (Eagleman, 2013). Pemasaran media sosial yang memanfaatkan aplikasi menjadikan media sosial sebagai perpanjangan untuk memenuhi pemasaran tradisional. Pemasaran kegiatan melalui aplikasi online memungkinkan terjadi kolaborasi antara komunikasi yang dihasilkan dengan penggunanya.

Pengabdian ini bertujuan untuk mengaplikasikan penggunaan media sosial yang digunakan untuk membantu Paguyuban Jip dalam memaksimalkan penggunaan media social dalam pemasaran jasa. Sehingga Paguyuban Jip mampu lebih optimal memasarkan jasa melalui media sosial. Berdasarkan latarbelakang di atas, kami sebagai civitas akademik Institut Asia Malang tergugah untuk memberikan pelatihan untuk meningkatkan pengelolaan sosial media dan strategi pemasaran pada Paguyuban Jip di Kabupaten Malang. Dengan adanya pelatihan ini diharapkan peserta pelatihan, yang terdiri dari pengurus, anggota dan non anggota paguyuban mampu memahami 
manfaat, pengelolaan, serta strategi pemasaran yang dapat diterapkan pada paguyuban Jip.

\section{Metode}

Subyek pengabdian ini dilakukan dengan paguyuban Jip 4x4 Bromo Tengger Semeru di kabupaten Malang. Waktu dan Tempat pelaksanaan pengabdian Sabtu, 8 Februari 2020, Pukul : 13.00-15.00 WIB di De Forest Rest Area Jl. Wisnuwardhana Tumpang. pengabdian yang digunakan dengan melalui pelatihan dengan metode presentasi, Tanya jawab, dan praktik. Dengan adanya pelatihan manajemen bersosial media ini, tingkat pemasaran para driver jip bromo tengger semeru diharapkan bisa meningkat. Proses perencanaan dan stategi digambarkan pada Gambar 1.

\section{Gambar 1}

Flowchart Pelaksanaan Pengabdian Manajemen Bersosial Media Dalam Strategi Pemasaran

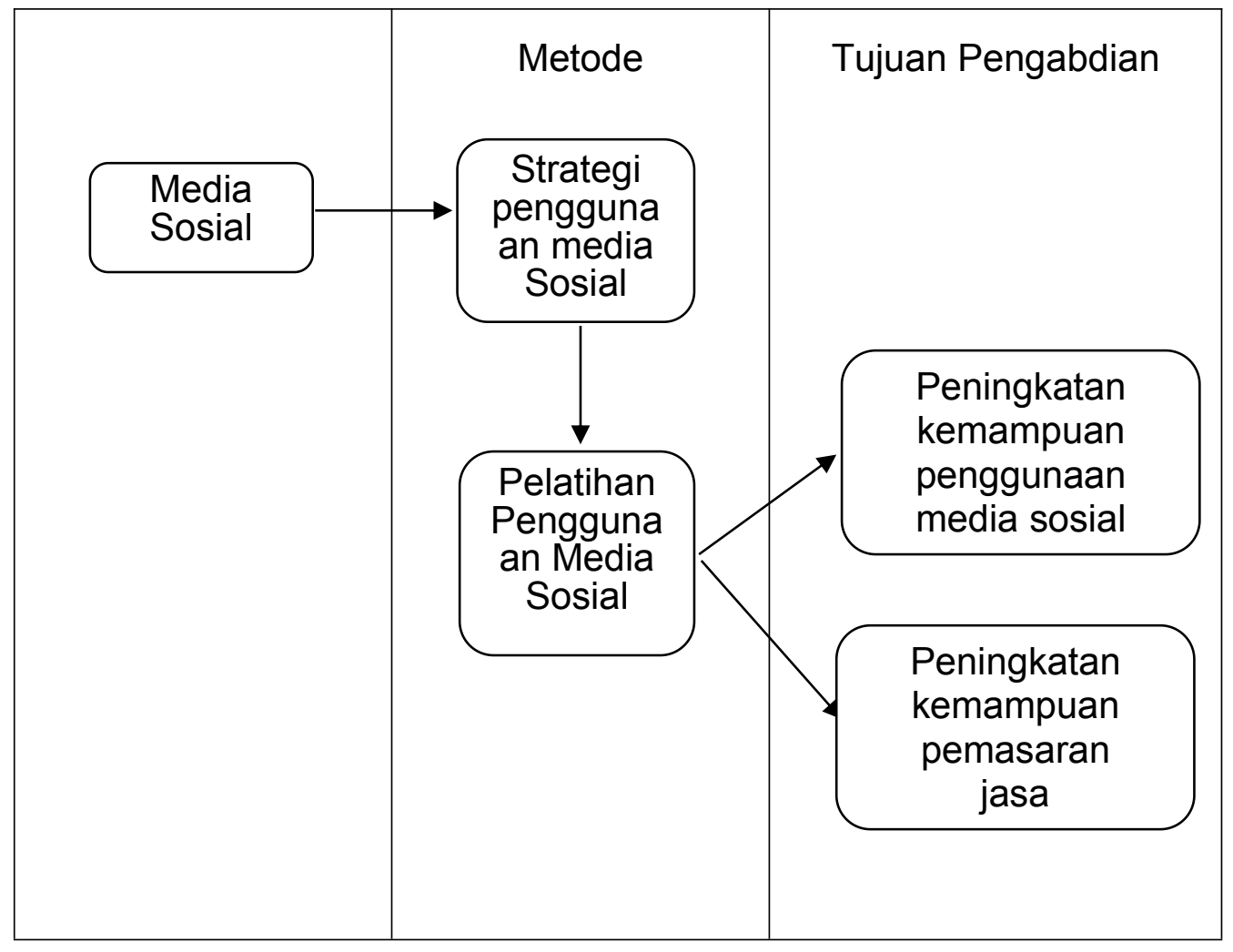


Gambar 1, menjelaskan bahwa konsep media social dalam pentingnya pemasaran jasa Paguyuban Jip, dengan metode yang dilakukan dengan melakukan strategi dan pelatihan penggunaan social media, sehingga tujuan pengabdian dapat meningkatan kemampuan dalam menggunakan media social dan pemasaran jasa.

\section{Gambar 2}

\section{Penyerahan Sertifikat}

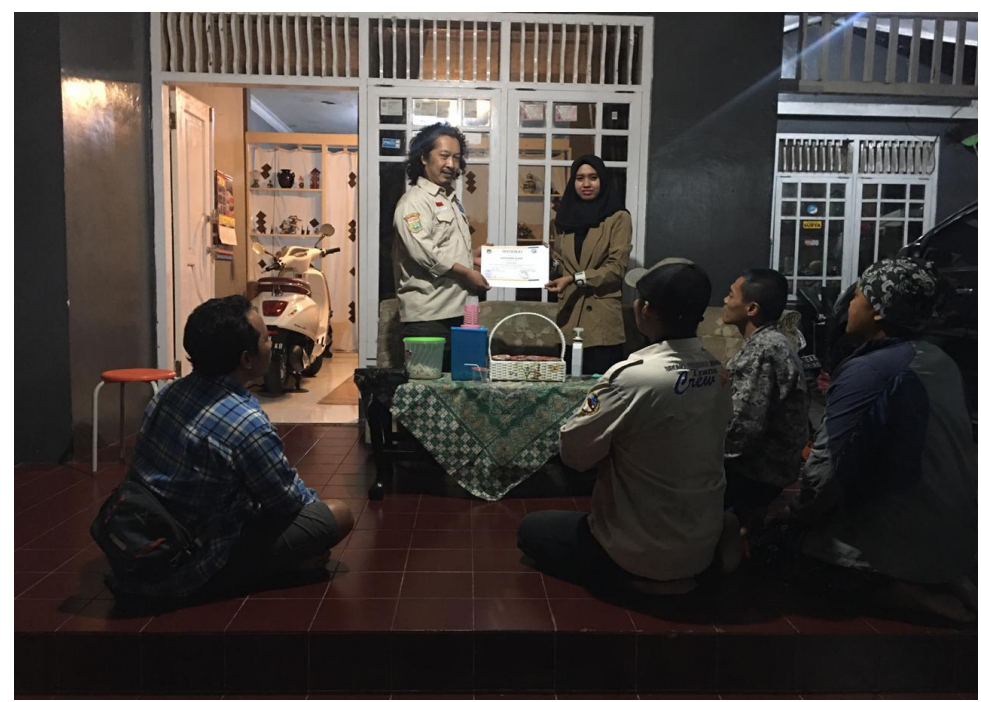

Gambar 3

Pemberian Workshop

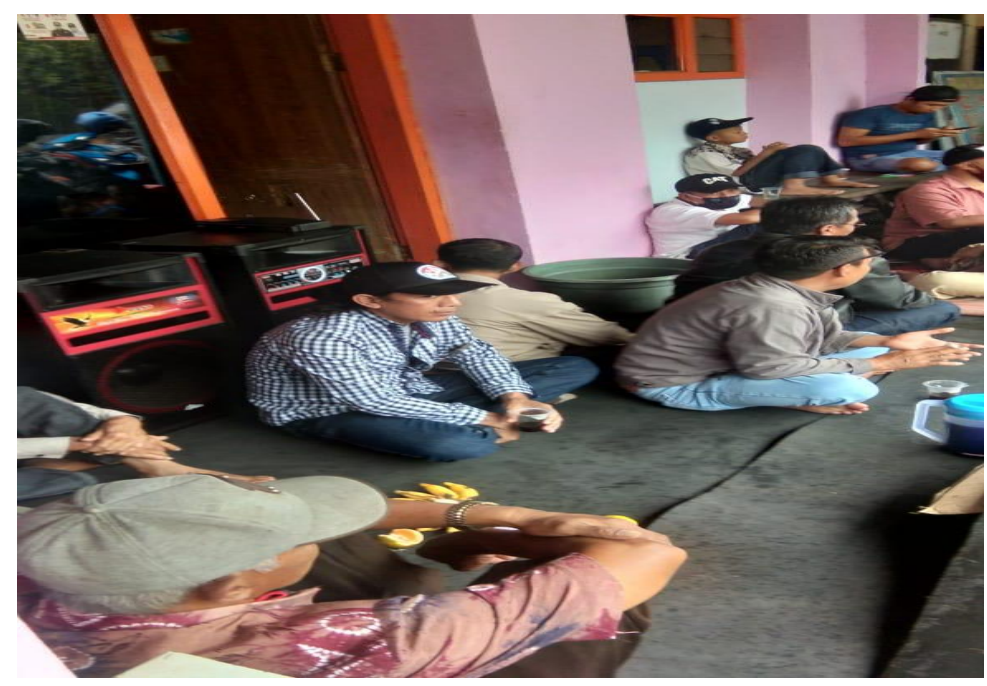




\section{Gambar 4}

Pelatihan Sosial Media

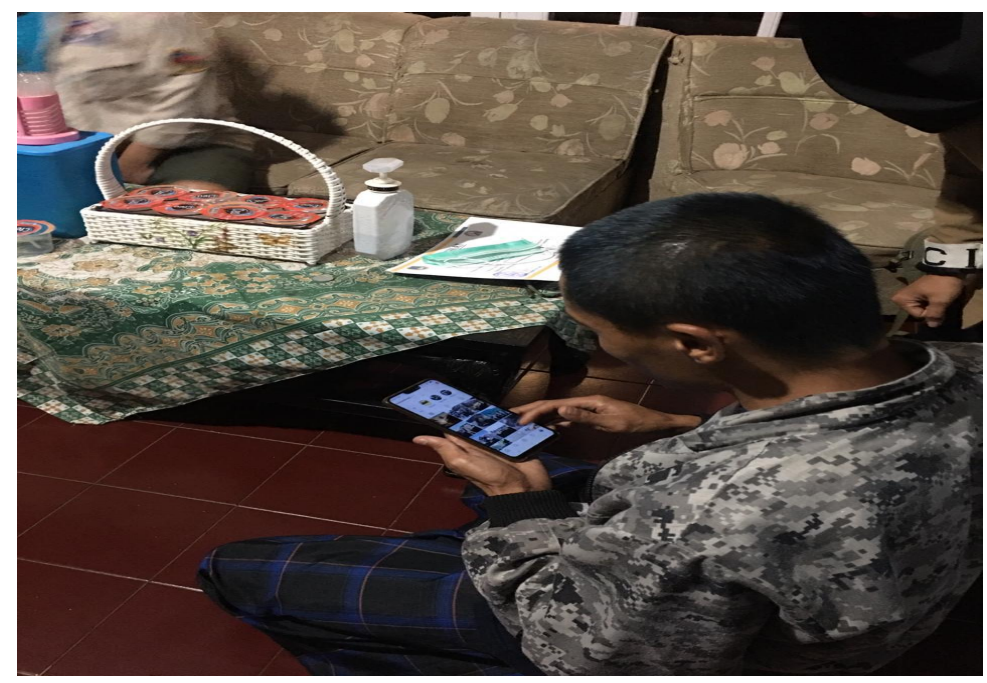

Hasil

Strategi penggunaan media sosial melalui pendekatan, sebagai berikut:

1. Perhatian

Untuk menarik perhatian melalui media sosial, dapat dimulai pada saat pemilihan nama untuk akun media sosial. Pilih nama yang mampu menarik perhatian. Untuk menarik perhatian dapat dilakukan melalui dua poin yaitu Be the worst atau Be the best. Untuk menarik perhatian dapat juga dilakukan dengan memajang produk di area display. Sebagai contoh area display pada instagram berada pada profile picture dan jangan lupa hastag yang banyak. Menjadi pengikut pada akun media sosial (instagram/facebook) lainnya untuk membuat bisnis anda diketahui orang lain. Ikutilah orang-orang / bisnis yang famous (terkenal). Pada langkah ini, anda tidak hanya menjadi pengikut pasif tapi aktif memberikan respon (komentar) positif terhadap postingan dari akun yang anda ikuti (teman anda). Misalnya setiap kali ada postingan dari akun yang anda ikuti (teman anda), anda harus cepat memberikan respon. Misalnya ada postingan seorang tokoh dari batam 
yang ke bromo, anda berikan respon "Semoga puas dengan pelayanan kami". Membuat konten untuk orang bisa berkomentar tentang postingan yang positif. Seperti: memasang foto perempuan yang menggunakan jilbab syar'i yang sedang bediri di bromo.

2. Menarik

Setelah mendapatkan perhatian, langkah selanjutnya adalah ketertarikan. Untuk melakukan ini ada tiga hal yang harus bisa kita sampaikan yaitu: apa mau kita; apa kelebihan kita; dan apa kekurangan kita. Guna menciptakan tertarikan di media sosial dapat dilakukan dengan memberikan tulisan pada bagian keterangan. Memberikan informasi yang jelas tentang produk, yang mencakup deskripsi singkat dari mereka fitur utama, harga, dan gambar. Pengguna media social diharapkan mampu mencatumkan informasi yang lengkap mengenai detail produk. Berbeda dengan metode konvensional, pelayan driver harus menghafal detail dari setiap produk / jasa wisata yang akan ditawarkan. Gambar produk/jasa harus relevan / sesuai asli dan disajikan dari sudut (angle) yang berbeda. Foto gambar produk / jasa jangan hanya tampak depan, gunakan dari berbagai sisi (angle). Hal ini akan memberikan pengaruh positif terhadap daya tarik calon pembeli.

3. Keinginan

Untuk mendapatkan keinginan dapat dilakukan dengan membuat tagline yang dapat menimbulkan keinginan dan ketertarikan untuk membeli. Dalam hal ini pada saar melakukan promosi melalui foto sampaikan pula manfaat dan efek yang bisa didapat saat menggunakan produk yang ditawarkan. Berikan promosi-diskon khusus, misalnya memberikan free 1 orang jika mengajak 5 orang. Perbarui media sosial "posting pada story" secara teratur. Melihat komentar dari para pengikut dan merespon dengan cepat. Menawarkan layanan pelanggan pra-penjualan yang baik.

4. Tindakan

Agar konsumen melakukan tindakan untuk melakukan pemesanan armada jip, pada tahapan ini yang dapat dilakukan adalah dengan mengenali siapa target 
pasarnya. Contohnya adalah apabila target pasar ibu-ibu maka lakukan dengan memberikan foto-foto spot yang menarik, sedangkan misalnya keluarga spot yang tidak extrim. Buatlah dalam bentuk gambar untuk memudahkan pengunjung memahami cara pemesanan.

Dengan ini diharapkan akan ada perubahan para driver Jip mampu dalam penggunaan social media sehingga jumlah pengunjung yang akan datang ke wisata Bromo, karena meningkatkan pemasaran Paguyuban Jip.

\section{Diskusi}

Berdasarkan pelatihan yang dilakukan ditemukan bahwa media social merupakan salah satu metode yang dapat diterapkan dalam melakukan strategi pemasaran bagi pelaku Paguyuban Jip, mengingat minimnya para driver yang masih belum bisa menggunakan media sosial. Artinya pengingkatan dalam penguasaan social media meningkat juga pemasaran jasa yang dilakukan.

\section{Kesimpulan}

Strategi penggunaan media sosial diharapkan mampu meningkatkan respon pada posting-an yang dilakukan; Pelatihan penggunaan media sosial memberikan tambahan wawasan bagi para driver paguyuban Jip. Implikasi dari hasil penelitian adalah para driver paguyuban Jip mendapatkan teknik yang lebih efektif dalam berjualan/promosi di media sosial. Sehingga berdampak positif pada branding/peningkatan omset usahanya.

\section{Pengakuan/Acknowledgements}

Terima kasih kami ucapkan kepada Ketua Paguyuban Jip, dan seluruh anggota yang telah mensukseskan pelatihan Manajemen Bersosial Media Dalam Strategi Pemasaran Paguyuban Jip4x4 Bromo Tengger Semeru Kabupaten Malang. 


\section{Daftar Referensi}

Eagleman, A.N., 2013. Acceptance, motivations, and usage of social media as a marketing communications tool amongst employees of sport national governing bodies. Sport Management Review, 16(4), 488-497. Haryani, S., dan Motwani, B., 2015. Discriminant model for online viral marketing influencing consumers behavioural intention. Pacific Science Review B: Humanities and Social Sciences, 1(1), 49-56.

Öztamur, D., dan Karakadılar, S.I.,, 2014. ScienceDirect Exploring the role of social media for SMEs: as a new marketing strategy tool for the firm performance perspective. Procedia - Social and Behavioral Sciences, 150, 511-520.

Rahmana, A., 2009. Peranan Teknologi Informasi dalam Peningkatan Daya Saing Usaha Kecil Menengah. In Seminar Nasional Aplikasi Teknologi Informasi (pp. 11-15). Yogyakarta.

Widiyanto, I., dan Prasilowati, S.L., 2015. Perilaku Pembelian Melalui Internet. Jurnal Manajemen Dan Kewirausahaan, 17(2), 109-112. 